\title{
Comment
}

\section{Senior moments}

\section{Gregory A Petsko}

Address: Rosenstiel Basic Medical Sciences Research Center, Brandeis University, Waltham, MA 02454-9110, USA.

Email: petsko@brandeis.edu

Published: I September 2006

Genome Biology 2006, 7: I I3 (doi:I0.I I86/gb-2006-7-8-I I3)

The electronic version of this article is the complete one and can be

found online at http://genomebiology.com/2006/7/8/II3

(C) 2006 BioMed Central Ltd

Almost thirty years ago, I was sitting in my basement office (they always used to put X-ray crystallography labs in the basement in those days - either because they were afraid the heavy equipment would crash through the floor or because they thought the radiation would contaminate people below - I never figured out which) at Unnamed Eastern University, trying to write a grant. I had only joined the UEU faculty a few days before, and the prospect of finding funds to support my scientific ideas - not to mention students to carry them out - was seeming particularly daunting that day. All the science buildings at UEU were connected by a rabbit-warren of underground tunnels, which included the corridor outside my office. Because UEU had never bothered to design its science buildings with any foresight, these tunnels were often used as storage rooms for the files, equipment and other paraphernalia that wouldn't fit in the labs upstairs. My office was located near the junction of the tunnel under the Chemistry building and that under the Earth and Planetary Sciences building, and right around the corner from my door were dozens of old wooden cabinets filled with geological specimens: meteorites, quartz crystals, petrified wood, stromatolites, fool's gold, trilobites, and hundreds of others. It was fun to go and look at them for a while on those long days early in my career when no one called, no mail came, and I was sick of writing.

But that day I was writing when suddenly a whole troop of very young undergraduates stormed into my office. They were all holding large pieces of paper and pencils. I had heard that, to help familiarize them with the geography of their new surroundings, UEU held a scavenger hunt for incoming freshmen, who had to go around campus marking the locations of various odd objects; apparently, these students were on such a mission. "Excuse us, Professor," one of them said, "could you tell us where we could find the fossils?"

"Well," I replied - and by my answer earned instant notoriety in the UEU community - "most of the senior faculty are on the third and fourth floors." Something - it doesn't matter what - reminded me of this episode a few weeks ago. I laughed thinking about it - at first. Then I realized that, if the same thing happened today, I would be one of the senior faculty I so cavalierly referred to. How did this happen? I don't think of myself as 'senior faculty'. Like most people, my mental picture of myself is rather different from my chronological age. If I think about it objectively, I would say that I usually imagine myself to be about as I was 10 to 15 years earlier, and that this has been true for much of my adult life. By no stretch of the imagination should a 43 year-old scientist be considered 'senior' in the sense I meant the term back at UEU.

But, of course, I'm not 43. I'm 58. Somehow, without my realizing it, I have become what I beheld. I'm suddenly past my prime, an object of pity or derision for my younger colleagues, old scientifically as well as physically. It isn't exactly like Gregor Samsa waking up one morning to find that he has metamorphosed into a giant insect, but it's close. All of which has led me to compiling a list designed to help those of you who may be in a similar situation. So that you will not one day be shocked to find that you have become senior faculty, here is a set of signs that will allow you to recognize the abyss as you approach it.

You are senior faculty if you can actually remember when more than $10 \%$ of submitted grants got funded.

You are senior faculty if you can remember when there was only one Nature.

You are senior faculty if you still get a lot of invitations to meetings, but they're all to deliver after-dinner talks.

You are senior faculty if students sometimes ask you if you ever heard Franklin in person, and they mean Benjamin, not Aretha.

You are senior faculty if a junior colleague wants to know what it was like before computers, and you can tell her. 
You are senior faculty when the second joint on the little finger of your left hand is the only joint that isn't stiff at the end of a long seminar.

You are senior faculty if you sleep through most of those long seminars.

You are senior faculty if you visit the Museum of Natural History, and the dummies in the exhibit of Stone Age man all remind you of people you went to school with.

You are senior faculty if you find yourself saying "Back in my day" or "When I was your age" at least twice a week.

You are senior faculty if you actually know what investigatorinitiated, hypothesis-driven research means.

You are senior faculty if you occasionally think that maybe you should attend a faculty meeting once in a while.

You are senior faculty when your CV includes papers you can't remember writing.

The problem, of course, with being senior faculty is not the inevitable lack of respect you get from your younger colleagues. That's as it should be: science is a young person's game. (They may even come to admire your wisdom, which is really nothing but experience, and ask you to read their papers and grants. Hopefully, they'll ignore your advice.) No, the problem with reaching senior status is the feeling that you have nothing much to contribute except experience. I was feeling that way myself until I read about the Neanderthal Genome Project.

A project to sequence the genome of Homo neanderthalensis, the last representative of which died more than 35,000 years ago, sounds like science fiction, but it isn't. Jonathan Rothberg and Michael Egholm, who work at 454 Life Sciences, a high-throughput sequencing company in Branford, Connecticut, USA, are doing exactly that, in collaboration with Svante Pääbo of the Max Planck Institute in Leipzig, Germany. The project, which was launched on 20 July of this year, takes advantage of the whole-genome shotgunsequencing technique developed by Craig Venter for the human genome sequencing project. In that method, the genome is broken up randomly into fragments about 100-200 base pairs long, which can be sequenced rapidly by machine. The final sequence is assembled from the fragments computationally, by using the overlaps between them. In the case of the Neanderthal genome, time has already broken the DNA up into fragments of just about that average length. The genetic material is being extracted from the right arm of a 40,000 year-old skeleton found in a cave in the eponymous Neander Valley in Germany. And 454 Life Sciences has novel technology for chip-based sequencing using emulsions to separate fragments so that each well on the chip has only one piece of DNA. (Disclosure: I have no connection with either 454 Life Sciences or its parent corporation, CuraGen.) The other hallmark of 454 Life Sciences' technology is the PicoTiterPlate, which allows a single instrument using patented light-emitting sequencing chemistries to produce, they claim, over 20 million nucleotide bases per 5 hour run, more than 60 times the capacity of instruments using the current macro-scale technology. Pääbo is an expert in, among other things, dealing with the problems of microbial DNA contamination of ancient samples.

Over the next two years, the Neanderthal sequencing team will reconstruct a draft of the 3 billion bases that made up the genome of Neanderthals. For their work, they will probably use samples from several Neanderthal individuals, including that specimen found in 1856 in Neander Valley and a particularly well-preserved Neanderthal from Croatia. The Max Planck Society's decision to fund the project is based on a preliminary analysis of approximately one million base pairs of nuclear Neanderthal DNA from a 45,000-year-old Croatian fossil, already sequenced by 454 Life Sciences. The Neanderthal genome sequence, which is expected to differ from that of the chimpanzee by about $4 \%$ overall, should shed considerable light on the evolution of Homo sapiens. Because the specimens being sequenced come from relatively late individuals in the history of $H$. neanderthalensis, they may also answer the long-standing question of whether the two humanoid species ever interbred.

If they succeed - and I'm betting they will - then the obvious next challenge would be to sequence the DNA of something even older. And that is where I have something to contribute. Since I am now senior faculty, I can contribute my DNA. After all, why stop at a Neanderthal when you can sequence a dinosaur? 